DOI : 10.24260/khatulistiwa.v8i2.1247

\title{
BEROAHAN, LOCAL TRADITION OF COMMMUNITY IN KOTABARU, MELAWI, WEST KALIMANTAN
}

\author{
M. Farid Migustio \\ Pontianak State of Islamic Studies \\ Email: faridmigustio80@gmail.com
}

\section{HIGHLIGHT}

- Beroahan in Malay Tradition

- Islam and Local Culture

- Kotabaru, Melawi

\begin{tabular}{|c|c|c|}
\hline \multicolumn{3}{|c|}{ ARTICLE HISTORY } \\
\hline Submitt & : & 7 June 2018 \\
\hline Revision & : & 14 June 2018 \\
\hline Revision & : & 28 June 2018 \\
\hline Minor & & \\
\hline Accepted & & 20 Aug 2018 \\
\hline Published & 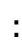 & 2 Sept 2018 \\
\hline
\end{tabular}

\begin{abstract}
Communities always have local wisdom for their interests and survival. Like wise with the community in Kotabaru, Tanah Pinoh District, Melawi Regency, West Kalimantan. Based on data obtained through interviews and observations at Kotabaru, the community inherited many local traditions; one of them is prayer. Beroah is a tradition of Kotabaru people who are chosen, carried out by people who want to do it, and usually carried out by capable communities. In the past until now prayers have always been carried out by Muslim communities to pray or send prayers to people who passed away. The aim is to pray for people who passed away. Prayers are usually carried out when the day of one's death and can also be carried out after the second, third, seventh, one hundredth and even one thousandth day.
\end{abstract}

Keyword:

Beroahan, Tradition, Kotabaru, Melawi

C2018 Khatulistiwa All Rights Reserved

KHATULISTIWA: Journal of Islamic Studies

Vol. 8, No. 2. September 2018
DOI: $10.24260 /$ khatulistiwa.v8i2.1247

Beroahan; Local Tradition of Community in Kotabaru, Melawi, West Kalimantan 


\section{A. INTRODUCTION}

Local culture is a wealth of local community inherited from generation to generation. This local culture has a very luxurious value for nation. (Arafah, B, 2003; Roisah, K, 2014) because the local culture makes us know about many local cultures. It is something valuable for our life around us including how to interact with nature and social life.

Local culture is very important thing to be preserved from generation to generation. Community takes the responsibility to continue the culture value and heritage from generation to generation. They feel anxious if the culture existence will be lost and extinct because of globalization era.

Beroah is one of the cultures in Kotabaru, Tanah Pinoh, Melawi Regency, West Kalimantan. It is the heritage culture from the ancestors which has cultural wealth value. Beroah is one of the culture form that must be carried out and inherited from generation to generation.

Beroah is a tradition carried out by the community to commemmorate and pray for the deceased or the souls of the deceased family. There are many opinions of Beroah. Some people view that this tradition must be carried out when the death is occurred. Some people believe that Beroah is the ancestors belief that must be carried out if there is someone passed away. Some people also believe if someone passed away, Beroah must be carried out, if it is not, the soul will not rest in peace.

The background of this article is the interest of writer in observing the uniqueness of Beroah in Kotabaru. The uniqueness are its valuable culture and form of the local community wisdom that it can not be found in other local communities.

Wisdom is one's ability in maintaining his mind in managing a situation. While local is an interaction where an event or situation occurred. So, substantially local wisdom is a value and norm obtained in a community as the references to act and behave in daily life. In other word, local wisdom is the ability to behave and empower the noble value of local culture. So that, local wisdom is the important entity in increasing human dignity in the community (Geertz, 1992)

KHATULISTIWA: Journal of Islamic Studies

Vol. 8, No. 2. September 2018
DOI: $10.24260 /$ khatulistiwa.v8i2.1247

Beroahan; Local Tradition of Community in

Kotabaru, Melawi, West Kalimantan 
Local wisdom is human intelligence of certain community or ethnic obtained from many experiences. It means that local wisdom is the creation of certain community through their experiences and unexperienced yet by other communities (Rahyono, 2009). Same as S. Swarsi, conceptually, local wisdom is a human policy based on institutialized phylosophy of values, ethics, ways, and behaviors traditionally. Local wisdom is a value considered good and right to be maintained in a long time and institutialized. (Mariane, 2013)

Phongpit and Nantasuwan stated that local wisdom is the knowledge based on people's experiences from generation to generation. This knowledge becomes the rules in community daily activities concerning with families, neighbors, communities, and environments (Affandi and Wulandari, 2012).

\section{B. METHOD}

This article is written based on data collection in the field conducted by the writer in Kotabaru, Melawi. Data obtained in this article are the result of observation in the field carried out by the writer in June 2018. The writer interviewed religious figures, community figures, and housewifes to get the description of Beroah tradition.

The interview was carried out in their houses directly and by teleconferences on the phone when the writer needed an additional information. Besides that, to get an accurate data, the writer also asked the informants to write Beroah prays.

The writer also did observation to complete the description of Beroah tradition and added by the writer's experiences as the part of Kotabaru's community. Data are collected and classified based on the research purposes.

\section{RESULT AND DISCUSSION}

\section{General Description of Kotabaru}

Once Kotabaru is called Kutabaru. The history of Kutabaru comes from a king who built a castle with ditches called Kuta and the word 'baru' comes from 'baru dibangun' (build recently). So, it is called Kutabaru. Now, Kutabaru are more famous with Kotabaru. Kota comes from the word 'kota' (city), so it is called Kotabaru (Khuzma Yudhi, interviewed on June 2018)

KHATULISTIWA: Journal of Islamic Studies

Vol. 8, No. 2. September 2018
DOI: $10.24260 /$ khatulistiwa.v8i2.1247

Beroahan; Local Tradition of Community in

Kotabaru, Melawi, West Kalimantan 
Kotabaru is the capital city of Tanah Pinoh district in Melawi regency of West Kalimantan. The population in Kotabaru is about 18,000 people and the number of villages are 11 villages, they are Sukamaju, Batu Begigi, Loka Jaya, Tanjung Gunung, Keranjik, Madong Raya, Bina Karya, Tanjung Beringin (Kampung Baru), Maris Jaya, Desa Bina Jaya, and Desa Pelita Kenaya village.

The majority of Kotabaru population are Dayak and Malay tribes. Dayak tribes are Dayak Keninjal, Dayak Lindi, Dayak Kasubang, Dayak Sandai, Dayak Pangin, Dayak Batu, Dayak Keluas, Dayak Meligai, and Dayak Melayu tribes. Islam is the majority religion in Kotabaru but there are also another religions such as Catholics, Christians, Congfucians, and so on.

In Kotabaru, there are also many cultures such as Jepin, Haprah, Gamelan, and Pencak Silat. These cultures are still alive in the midst of community and presented in a certain event. Kotabaru community live from farmings, tapping rubbers, gold miners, employees, labours, and so on. The dependence of the community on natural resources is very high (Syaifu Tito, 57 years old, Kotabaru, Melawi, June 28th, 2018).

\section{Form of Beroah Tradition}

In the past until nowadays, Beroah always be carried out by Moslem community when there is a person who passed away. Beroah is carried out in three days, seven days, fourty days, one hundred days and one thousand days. Carrying Beroah is the tradition of Kotabaru's community. It is not obligation for the people who uncapable to carry out this Beroah. It is only for capable people who can carry out this tradition. Beroah will be carried out in many certain months such as Sya'ban before Ramadan or Ied Al-Fitri, before and after Ied al-Adha, and Yasinan held every Friday night.

Beroah is aimed to commemmorate and pray to person who passed away and also pray for families to get the patience. In Beroah, community prepare some foods such as cakes, meals, and vedgetable soups in a big plate with side dishes. The foods are eaten by the people who invited in the event especially neighbours and families to eat together after Beroah pray.

There are many forms of Beroah local wisdom but because of a limited chance, it is only a few events discussed in this article. The local wisdom of Beroah, in three days and so

KHATULISTIWA: Journal of Islamic Studies

Vol. 8, No. 2. September 2018
DOI: $10.24260 /$ khatulistiwa.v8i2.1247

Beroahan; Local Tradition of Community in

Kotabaru, Melawi, West Kalimantan 
on, will be discussed as follow. There are two types of Beroah tradition in the community. First, an annual Beroah. It is not obligated for uncapable people, but only for capable people. So, the procession depends on the family. This Beroah can be carried out in Sya'ban, before Ramadan, after Ied Al Fitri and Ied Al Adha. Recently, people are carried out Beroah in another months based on their capability and timing. The procession is not always carried out annually. Sometimes, it is carried out after a few years later.

Second, Beroah carried out by people after the person who passed away is burried and tahlilan and Beroah are carried out at night. This Beroah must be carried out by the family of person who passed away. This second Beroah is carried out a few times; in the first, second, third, seventh, fourtieth, hundredth, thousandth and first year. Beroah is identic with praying together by reading a specific pray such as roah pray added by selamat and tolak bala' pray.

After praying together, called Pongel, the people are invited to eat the served meals together in face to face position but now the meals are served on a table not in a big plate. The serving depends on the host choice based on their facilities prepared.

Nowadays, the procession of Beroah is different with its procession in the past time. In the past, the invited people are only men, but now women are also invited. Usually Pemongel (an invitee) invites all families in their houses (berobis). When the event is carried out, the place between men and women are separated. The men are welcomed to sit in the living room and the women are in the kitchen.

\section{First Day of Death}

At the first day of death, the family will buy some foods ingredients and cook them for the people who are invited by the family of passed away person and the people who dig the cemetery. The people bring some food as their charity to the family of passed away person. The foods are rice, coconuts, salt, and another foods. The host is only prepare or buy some side dishes. They cook rice and side dishes such as umbut vedgetable soup (palm or coconut tree), soy sauce chicken, starfruit spicy sauce and so on.

The host also makes particular cakes such as Serabi and Lintang Natai (pucung) cake. Serabi cake is a round thin cake made from rice flour and grated coconut. Lintang Natai cake is made from rice flour, grated coconut, some salt, oil for frying, and some water.

KHATULISTIWA: Journal of Islamic Studies

Vol. 8, No. 2. September 2018
DOI: $10.24260 /$ khatulistiwa.v8i2.1247

Beroahan; Local Tradition of Community in

Kotabaru, Melawi, West Kalimantan 
In Kotabaru, Serabi cake is rarely found because this cake is only as the completion for death event. Families believe that making this cakes means invite the death so they will not make Serabi cakes for daily meals. It is pamali (impolite). Serabi cakes are made for about fourty cakes and given to the children (Titi Sumantri, 48 years old, interviewed in June 2018).

\section{Second Day of Death}

On the second day, the host invite, called mongel, the neighbours and the nearest families for two reasons; to attend Beroah event and help to cook some meals to be served in Beroah event. The meals in the second day are different with the first day. In the second day, the families make Peturak and Juadah cake. Peturak cake is made from rice flour, coconut milk, salt, and banana leaves to wrap the cake with a small rope. The ropes are sometimes taken from the banana leaves. The number of Peturak cakes are fourty cakes and sometimes more than fourty. Juadah cakes are also made for about fourty cakes and sometimes more than fourty to avoid the lack of cakes.

Generally in the second day, Kotabaru community still make Peturak cake. The ingredients are rice flour, coconut milk, salt, banana leaves to wrap it, and rafia rope to tight it up. The way to cook it, first, rice flour mixed with coconut milk and salt, stir it well. Then prepare banana leaves to wrap it in silinder form and tied it up in the tip of cake. Tied also in the midst of cake. The tip of cake are tied like a bar or silinder form. The tip and the lower part of cake are also tied up. Then it is put in silinder form and boil until cook.

Peturak is made at least for fourty plates. Peturak cake is also rarely found in ordinary days and it is usually in particular days at Beroah event.

Peturak cake is different with the past. The differences are the cake is dry cooked, unliquid form, and the mixture are cooked. When it is half cooked, then it is wrapped with banana leaves. People prefer to use gas stove than firewood.

Juadah cake is one of usual cake in Beroah event in Kotabaru. Like Serabi and Pucung cake, Juadah cake is rarely found in ordinary days. The way to make this cake is preparing the ingredients such as rice flour, coconut milk, palm sugar, and sugar. First, mix the rice flour, coconut milk and sugar. Then, the mixture is put in a big frying pan (tapsi) then it cooked in a

KHATULISTIWA: Journal of Islamic Studies Vol. 8, No. 2. September 2018
DOI: $10.24260 /$ khatulistiwa.v8i2.1247

Beroahan; Local Tradition of Community in

Kotabaru, Melawi, West Kalimantan 
big kuali and covered by a big kuali cover for thirty minutes. After it is cool, it is cut into square or parallel form. This cakes are made for about fourty cakes.

\section{Third Day of Death}

In the third day, the host invite the neighbours and nearest families. The different is the meals. The meals are rice and side dishes like umbut soup, soy sauced chicken, and starfruit spicy sauce. They pray by reading roah pray and tahlilan. They are having meals together in a big plate.

Umbut soup is served in Beroah. It comes from a stock of coconut or palm tree. Palm trees are planted by people as productive plants to substitute rubber trees. While coconut trees are planted as additional plants around the house.

Umbut is cooked with fat or coconut milk. The ingredients are umbut of coconut, salt, shrimp paste, sugar, flavours, pepper, coriander, garlic, onion, galangal, ginger, chilli, coconut milk, and oil for frying. How to cook it is cut the umbut, slice it, and cut about two fingers length. Then, all the ingredients are smashed smoothly. Fried it well, then put in the umbut, coconut milk, salt, sugar, and flavours. It uses firewood and a big pan (kuali).

Another meal in Beroah is soy sauced chicken. The ingredients are chicken, soy sauce, coconut milk, coriander, spinning, pepper, ginger, galangal, lemongrass, turmeric, salt, flavours, sugar, nutmeg, cloves, cinnamon, and oil fr frying. It also us es firewood and a big pan (kuali).

The host also prepare chilli sauce as the completion. Chilli sauce is made from starfruit, coconut milk, chilli, lemongrass, turmeric, galangal, ginger, salt, sugar, flavours, garlic, onion, coriander, and mixed with chicken intestines if any, and oil for frying. Starfruit is thinly sliced and soak with salty water. Then, smashed, washed, and drained it. All the ingredients are smashed smoothly then fried it well and put in the starfruit. The chicken intestines can be mixed in it if any.

Carrying Beroah in the seventh and fourtienth days are same as the third day. The similarities of both are read roah pray, tahlilan, and having meals together with the neighbour and families. It is also for the hundredth and thousandth days.

KHATULISTIWA: Journal of Islamic Studies

Vol. 8, No. 2. September 2018
DOI: $10.24260 /$ khatulistiwa.v8i2.1247

Beroahan; Local Tradition of Community in

Kotabaru, Melawi, West Kalimantan 
In Beroah event, the guests are served by some meals. This serving is interesting to be discussed because it describes a specific thing in this tradition that it is not described in other places in Kotabaru.

The serving prepared are rice in prontang (rice bowl), soy sauced chicken in a medium bowl, umbut soup in a bowl, chilli sauce in a small plate, and hand-washed water in a bowl. The guests must wash their hands before having meals together. The food that has been served must be placed in the middle and stretched out in the room then the guests or people who have been pongel have to sit face to face. So prontang dishes must be in the middle.

After all the people gather, they will read tahlilan and read roah pray. A religious leader became the leader of this event. As the change of time, now the food is served on the table, using resin and rarely using a small cobok or bowl for washing hands became change because many people already use a spoon. (Titi Sumantri, 48 years old, interview 1/28/2018)

In 1980, the communities are carried out tahlilan or roah to pray for the passed away person. This activity must be carried out by the families. If it is not carried out, the families feel something is missing.. When a person passed away, one of the families will be in the cemetery for three days to read tahlilan and read Quran continuously.

While the other families carry out tahlilan and roahan for three days by inviting neighbours and families. Before tahlilan, it is prepared some burned incenses put in the middle of the guests. Fumigation is ended after read tahlilan and roah pray. In 1980, the tradition of fumigation begin to be removed. Tahlilan with fumigation and staying in the cemetery are vanished. Both are vanished because they are too exessive.

\section{CONCLUSION}

Beroah in Kotabaru Melawi community shows its uniqueness. It is inherited culture from previous generation related to Islamic elements. Community believe Beroah is inseparable part of life as culture inheritance and moslems. This culture is a hereditary inheritance from generation to generation. It must be maintained because there are benefits and goodness behind it.

Beroah has a religious value in reaching Alloh's blessing and praying for person who passed away. Togetherness is built here. This togetherness can be seen in many activities in

KHATULISTIWA: Journal of Islamic Studies

Vol. 8, No. 2. September 2018
DOI: $10.24260 /$ khatulistiwa.v8i2.1247

Beroahan; Local Tradition of Community in

Kotabaru, Melawi, West Kalimantan 
Beroah such as digging cemetery, cooking some meals for the guests, attending Beroah, and so on. Because of its noble value, this culture can be maintained since nowadays eventhough many changes and adaptation are occurred.

This research has limited time and focus, so it cannot reach the whole information about local wisdom of Beroah especially prohibition in Beroah that have not described yet in this article..

KHATULISTIWA: Journal of Islamic Studies

Vol. 8, No. 2. September 2018
DOI: $10.24260 /$ khatulistiwa.v8i2.1247

Beroahan; Local Tradition of Community in Kotabaru, Melawi, West Kalimantan 


\section{BIBLIOGRAPHY}

Affandy, D., \& Wulandari, P. (2012). An Expliration Local Wisdom Priority in Public Budgeting Process ol Local Government. Jakarta: Rineka Cipta.

Arafah, B, (2003). Warisan Budaya, Pelestarian dan Pemanfaatannya. Fakultas Ilmu Budaya, Universitas Hasanuddin. Artikel.

Geertz, C. (1992). Kebudayaan dan Agama. Yogyakarta: Kanisius Press.

Khuzmayudhi. (2013). Sejarah Awal Mula Nama Kotabaru (Tanah Pinoh, MELAWI). Diakses Desember, 1, 2018, dari http://khuzmayudi.blogspot.com /2013/03/ sejarah-awalmula-nama-kotabaru-tanah.html

Mariane, I. (2013). Kearifan Lokal Pengelolaan Thompson. Paris: Cambridge University. Rahyono, FX. (2007). Kearifan Budaya dalam Kata. Jakarta: Wedatama Widyasastra.

Roisah, K, (2014). Perlindungan Ekspresi Budaya Tradisional dalam Sistem Hukum Kekayaan Intelektual. Masalah-masalah Hukum 43 (3): 372-379.

Interviewee:

Syaiful Tito, 57. Kotabaru, Melawi

Titi Sumantri, 48. Kotabaru, Melawi

KHATULISTIWA: Journal of Islamic Studies

Vol. 8, No. 2. September 2018
DOI: $10.24260 /$ khatulistiwa.v8i2.1247

Beroahan; Local Tradition of Community in Kotabaru, Melawi, West Kalimantan 